УДК 72.071.1 Јовановић К.

725(497.11)"18/19"

\title{
ДУШИЦА НИкОЛИһ
}

\section{БЕОГРАДСКЕ ИНТЕРПОЛАЦИЈЕ АРХИТЕКТЕ КОНСТАНТИНА ЈОВАНОВИЋА}

\begin{abstract}
САЖЕТАК:
Овим радом актуелизујемо цивилизацијски допринос архитекте Константина Јовановића у изградњи Београда, који је, захваљујући њему, добио изглед европске престонице. Кроз своја остварења, здања попут Народне банке, Задужбине Николе Спасића и других, Јовановић је препознат као културни еманципатор који је српску архитектуру повезао са средњоевропском. Поготово су његове надахнуте интерполације допринеле преображају Београда из османске вароши у европски град. Недовољно разматране, заслужују посебну историографску пажњу.
\end{abstract}

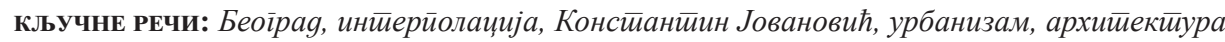

\section{ABSTRACT:}

The aim of this paper is to underline the fundamental contribution of Konstantin Jovanovic to the architecture of Belgrade, which, thanks to him, acquired the shape of a European capital. Thanks to his architectural achievements, like the building of the National Bank or the Endowment of Nikola Spasić, Jovanović was seen as a cultural emancipator who had brought Serbian architecture closer to the Central European standards. His inspiried interpolations greatly contributed to the transformation of Belgrade from an Ottoman town to a European city. As this contribution has been given little consideration, it deserves special historiographic attention.

KEYWORDS: Belgrade, interpolation, Konstantin Jovanović, urban planning, architecture

\section{Појам и врсте интерполација}

$\mathrm{M}$ атематички гледано интерполација ${ }^{1}{ }^{\text {je нала- }}$ жење међувредности у низу утврђених вредности. У архитектури се употребљава као термин за означавање интервенција у дефинисаном простору, испуњавању празнина у таквом простору. То је принцип уједначавања просторних односа унутар постојећег ткива, убацивањем нових просторних волумена или елемената да би се повезали раздвојени делови и постигла целовитост појма, или да би се неутрализовала последица деловања спољашњих чинилаца у простору, као што су пожар, земљотрес, рат или нека друга непогода која би могла девастирати и уништити целовитост објекта. На микроплану интерполација подразумева интервенцију на једном објекту уколико је услед спољних чинилаца прекинут континуитет просторне кохезије грађевине као целине. На макроплану, интерполацијом се схвата свако зади- рање у просторну контуру старог градског језгра у целини. ${ }^{2}$ Интерполацијом се може сматрати и свако уклапање нове архитектуре у околину. ${ }^{3}$ То је свако физичко додавање пуног које квалитативно мења дотадашњу морфолошку структуру, а не попуњава је, дакле само физички, квантитативно. ${ }^{4}$

Интерполација је архитектонски задатак у којем је захтев за усклађивање са околином један део спектра пропозиција. Упознавање пројектног задатка, прве анализе програма, сагледавање места за изградњу јесу елементи који упућују на ток размишљања. У том контексту неопходно је извршити процену квалитета постојећег окружења, а затим и определити се за одговарајући метод којим ће објекат успоставити дијалог са околином. Околина, амбијент, као и непосредни суседни објекти требало би да буду само подстицај за инспирисање архитектонског дела, а као посебан про- 
блем оставља се фиксирање габарита новог објекта. Неретко се дешава да архитекти сами поставе принципе за предлоге интерполација у историјским језгрима, одбијајући подређеност суседним објектима и често настоје да историјско наслеђе супротставе модерности. Требало би имати на уму да чак и тада, такво решење мора бити допуњено маштовитошћу и талентом архитекте. ${ }^{5}$

Интерполација може бити различита, како у контексту стилских изражајних средстава тако може зависити и од специфичних локалних обележја, традиције, конфигурације терена, расположивости материјала и новчаних могућности, политичке ситуације, укуса наручитеља. Свако поднебље има своју просторну традицију па се на међународном плану организују архитекти и конзерватори и одлучују норме понашања у старијим и вреднијим градским и другим просторним целинама да би се на време схватиле вредности једних од пуке потребе за интервенцијом других. С тим у вези, на конгресу Међународног савета за споменике и целине (ICOMOS), у оквиру Унеска, одржаног 1972. године у Будимпешти, један део се односио на интерполације и тада су усвојене четири битне конвенције. Прва је подразумевала важност урбанистичког планирања, што је значило да се морају узети у обзир постојећа просторна ткива па тек онда разматрати могућности интеграције савремене архитектуре. Друга је истицала слободну употребу нових техника и материјала, с тим што је неопходно водити рачуна о постојећем односу маса и ритма. Трећа се односила на аутентичност историјских амбијената, а компромитовање њене вредности уношењем другачијих стилских концепција није дозвољено. Четврта наглашава важност ревитализације и истиче могућност нових намена, с тим што све то не сме разорити историјску структуру амбијента или града. ${ }^{6}$

Битан чинилац селекције требало би увек да буде функционалност, а уклањање делова грађевине који могу служити сврси не би требало да буде дозвољено, већ се мора постојећа архитектура прилагодити новој намени. Архитекти морају увек бити свесни да својом интервенцијом залазе у домен прошлости, па тако расте одговорност и критичност, а аутор на тај начин успоставља равнотежу између свог објекта и околине која може бити успешна а и не мора.

У погледу различитих метода који се користе приликом интерполирања, Мароевић истиче метод факсимила што подразумева понављање оне исте архитектуре која се ту претходно налазила и која је допри- носила целовитости амбијента. ${ }^{7}$ Следећи метод јесте метод прилагођавања који подразумева већу валоризацију постојећег амбијента, а мање наглашавање нове архитектуре, и тиме се постижу већа структурална и визуелна неутралност објекта у односу на околину. Метод наглашавања у својој суштини подразумева метод прилагођавања, с тим што сада архитекта у једном тренутку има потребу да нагласи један елемент свог дела. Такво наглашавање може подразумевати истицање положаја самог објекта, значења или величине. Можда најтежа метода јесте метода контраста, која подразумева надјачавање уметнутог објекта својим изгледом, који жели да пошаље јасну и прецизно конципирану поруку. ${ }^{8}$

У читавом процесу интерполација неопходно је тражити најмањи заједнички фактор који је адекватан за сва три повезана објекта. Такође мора се водити рачуна и о постојећим елементима, као што су волумен, висина, просторна организација, хоризонтална и вертикална фасадна подела. Њихов урбанистички положај је такође важан, јер и само место интерполације утиче на сложеност релација. Ако се узима у обзир урбанистички положај, могуће је извести следеће поделе објекти с наглашеним углом, с наглашеном средином и објекти који стоје на почетку блока. Ако пак посматрамо намену интерполираног објекта, тада можемо говорити о стамбеним, пословним, управним, просветним и другим објектима... Ако гледамо кроз унутрашњу просторну концепцију, интерполирани објекти могу бити једнотрактни и вишетрактни. Уколико сагледавамо урбанистички развој града, онда такви објекти могу бити део улице, трга или парка, али и производ специфичне ауторске методологије појединца. ${ }^{9}$

Ако разматрамо поделу интерполација у ширем контексту, као и њену могућност да својом новом вредношћу валоризује постојећу вредност, неопходно је истаћи и неке важне премисе. Постојећа просторна композиција представља прошло време, а уметнути објекат садашње. Често се у том опсегу сусрећу интереси једних и других струја, односно конзерватора и архитеката. Будући да и једни и други играју важну улогу у том процесу, подједнако као и урбанисти и пројектанти, неопходно је превазићи ову временску препреку и заједничком акцијом доћи до позитивних резултата. Пракса је доказала да се њиховим раздвајањем често нарушавају савремена архитектура и градитељско наслеђе, с тим што је губитак једне вредности баштине тежи од одбијања једног савременог архитектонског остварења. Оно што би било добро то је да архитекти буду подједнако заинтересова- 
ни за прошлу као и за садашњу архитектуру, чији су склад и јединство препознали, јер од тога зависи судбина градитељског наслеђа и савременог архитектонског урбанистичког пројектовања. Зато је неопходно да се пре сваког разговора о било каквој интерполацији најпре удаљимо да бисмо видели целину, али не само ону тренутну перспективу између два суседна објекта већ је неопходан и онај просторно-временски поглед на прошлост, који је саставни део квалитетног грађевинског програма. ${ }^{10}$

\section{Интерполације Константина Јовановића у Београду}

Новију архитектуру Београда обележиле су интерполиране грађевине различитог типа - подужни огранци градских блокова с континуално повезаним прочељима окренутим једном уличном правцу, објекти усмерени ка ширим урбанистичким потезима, слободностојећи и у блок узидани објекти. ${ }^{11}$

Beћ у првом налету таласа интерполација покренутом на празним парцелама, а и касније у виду замене постојећих дотрајалих зграда већим и функционалнијим, није се водило рачуна о визуелно-стилској усклађености новоизграђених и затечених суседних објеката. Тек се крајем XIX и почетком XX века, посредством мера грађевинског законодавства, уводи неопходан ред који подразумева висински, ивични и нивелациони склад целина. Ипак, манир креативног уграђивања значајних градских простора није јењавао ни касније и није заобишао ни најрепрезентативније престоничке зоне попут улица Кнеза Михаила, Краља Петра, Васине, Коларчеве... Недовољно уважавање градитеља, амбициозност наручилаца, недостатак оштријих мера, честе смене архитектонских идеологија, али и развојни дисконтинуитети српског друштва, довели су до неуједначености спратних волумена и несклада у регулацији водоравних зона. ${ }^{12}$

Пракса наметљивог уграђивања у почетку се развијала уметањем спратних објеката између постојећих нижих, а касније се и тематски проширила на просторно и пластички обухватније уграђивање, кроз акцентовање угла, постављање нове целине уз једног $c y$ cega, захватање простора двеју па и више улица, кроз интерполирање на интерполацију и йломбирања ширих локација. Први интерполацијски подухвати стилских и композиционих шаренила индивидуалних зграда који сачињавају блок, постали су обележја београдског миљеа. Само ретки архитектонски подухвати настали у периоду од 1865. године до 1941. дају утисак контролисаности и умерености. ${ }^{13}$
Развој београдских интерполација текао је кроз праксу креативног фасадизма од 1926. године, преко неговања неупадљивих интерполација (1928-1931), до периода зрелог (1931-1935) и позног (1935-1941) предратног модернизма, када су се развијала ауторски амбициознија уграђивања која су била употпуњена заводљивим мотивима ар декоа или различитим истористичким евокацијама. Након периода соцреализма (1945-1952), интерполирање није било могуће због материјалне оскудице, али и деперсонализоване праксе, па тако од шесте деценије 20. века београдски модернисти започињу еру екстремно неконтекстуалног уграђивања која ће трајати до осамдесетих година. Они су често потенцирали агресивне облике, одражавајући дух архитектуре брутализма, касне модерне и хај-тека. Тек са генерацијом постмодерне приступа се пажљивијем и обазривијем извођењу интерполација, што подразумева уважавање духа места, навике и намене амбијента. Од средине деведесетих година и касније са обновом модерног архитектонског језика у виду неомодернизма оживљава се пракса бескомпромисних интерполација. ${ }^{14}$

Делатност Константина Јовановића (1849-1923) као архитекте на београдској градитељској сцени везана је за економски, политички и културни развој који je Србија доживела након проглашења Краљевине. ${ }^{15}$ Све важне привредне и културне институције својом архитектуром визуелно су изражавале своје европско опредељење, а томе је тежила и све моћнија српска грађанска елита. Репрезентативне породичне куће богатих београдских инвеститора, министара, адвоката и трговаца подигнуте су у последњој четвртини XIX века и дела су најугледнијих градитеља тог времена. ${ }^{16}$

Ангажовање Јовановића у Београду било је повезано како његовим познанствима с водећим личностима београдске културне и политичке сцене, и породичним угледом, тако и његовим образовањем и међународном репутацијом због које је, као ученик Готфрида Семпера (Gottfried Semper 1803-1879), био веома цењен међу српском грађанском елитом. ${ }^{17}$ Читав период Јовановићевог стварања представља цветно доба у развоју архитектуре Београда, односно време када град добија физиономију европске престонице. Јавне грађевине подизане су према прописаном типолошком обрасцу; грађене у неоренесансном маниру и у строгој симетрији изражавале су снагу и стабилност државе, а настале су комбиновањем главног мотива и споредних просторија. Његови објекти у Београду имају угаоне основе, али постоје и подужни развијени типови. Спољашњим третманом све оне изражавају важност институција које су у њима смештене. 
Његова архитектура носила је особен израз еклектичких схватања друге половине XIX века. У разнородној понуди историјских стилова, архитекти су тежили стварању сопственог идентитета унутар стила који су подражавали. Еклектичари се опредељују за фрагмент или целокупан опус неког истакнутог градитеља који је својим делом обележио епоху и имао утицај на развој архитектуре. Тако је Готфрид Земпер сматрао да једино архитектура ствара оригиналне формације и да једино она свакоме остаје читка и разумљива, за разлику од сликарства и вајарства који су миметичке уметности. Земпер је саветовао своје студенте да најпре упознају укупан развој уметности и савремену технику како би могли ускладити нову грађевину с постојећим архитектонским наслеђем. Јовановић је био један од таквих који је користио техничке тековине свога века, али их је уводио са опрезом. Зидови његових грађевина начињени су од опеке, међуспратне конструкције су дрвене са гвозденим и решеткастим носачима, стаклене површине су такође присутне. У складу са градитељском теоријом, објекти су обложени ренесансним омотачем. Ова његова опредељеност за ренесансу исход је теренског истраживања ренесансних споменика на самом извору, као и утицаја његовог професора Земпера. Прилагодљивост ренесансе духу у којем је Јовановић живео и потребама народа један је од разлога што се он потпуно определио за тај историјски стил. ${ }^{18}$

У Београду је израдио већи број пројеката, али нажалост неки нису никада ни реализовани док су поједини порушени у Другом светском рату. Данас постоји девет његових грађевина и један споменик посвећен националном хероју (коњаничка статуа кнеза Михаила). Радио је велики број стамбених објеката и они су углавном двојне, пословно-стамбене намене, с локалима у приземљу и становима на спрату.

У спољашњој обради фасаде уочљива је академска доследност и симетрија има доминантну улогу. Фасада је подељена профилисаним венцем на доњу рустичну зону и горњу зону мирне обраде. Куће су завршене истакнутим профилисаним кровним венцем, са атиком и балустрадом изнад њега. Отвори за комуникацију су лучно завршени. Прозори су завршени правоугаоно, с тимпанонима сегментних и троугаоних облика или са архитравним гредицама. Јавља се и балкон у висини првог спрата. Куполе нису увек присутне и то зависи од локације, намене и величине објекта. Хоризонтална подела истакнута је кордонским венцем, а вертикална ризалитима, куполама и пиластрима. Целокупан његов опус одише монументалношћу академске строгости са изразитим осећајем за хармонију. ${ }^{19}$
Анализом Јовановићевих интерполираних објеката у Београду добија се неколико типологија. Према урбанистичком положају који објекти заузимају, може се говорити о угаоном интерполирању (које је уједно и најчешће), о интерполираном објекту у низу, уграђеном типу са две стране, о уграђеном типу са више страна и о накнадном дозиђивању. Према начину финансирања објекта, разликујемо интерполиране објекте јавне и приватне намене. У даљем тексту биће размотрени сви објекти појединачно.

Народна банка је једини Јовановићев објекат јавне намене и пример је уграђеног типа с више страна. Грађевина је постављена тако да усмерава улицу и маркира урбанистичку препознатљивост града. Подигнута је 1888. године, а завршена 1890 , а њеном изградњом истакнут је пословни значај краја у којем je саграђена. Првобитно угаоно решење наметнуто је због неправилности парцеле на којој је зграда подигнута, на углу између улица Цара Лазара, Краља Петра, Николе Спасића и Грачаничке. Каснијом доградњом (1922-1925), коју је такође извео Константин Јовановић, објекат је добио петоугаону основу и тако заузео целокупну површину затвореног урбанистичког блока. У таквој форми блока са унутрашњим двориштем зграда је остала сачувана до данашњих дана.

Привредни успон Србије условио је подизање такве импозантне грађевине каквом се могла похвалити свака европска престоница. Заснована на архитектури италијанских палата ране ренесансе, она

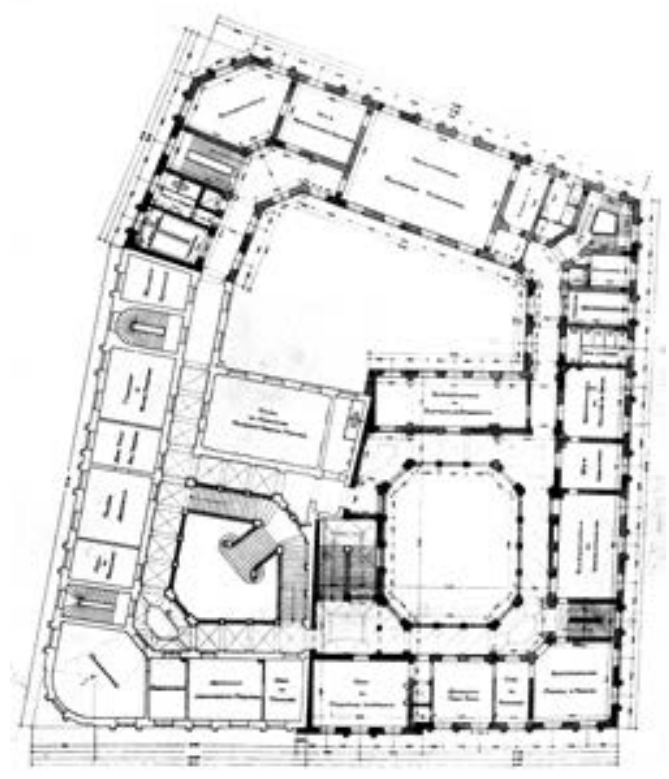

Сл. 1 / Основа йрвої сиратиа, йлан из 1922. іолине

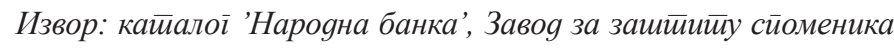
кулйуре їраgа Беоїраgа 


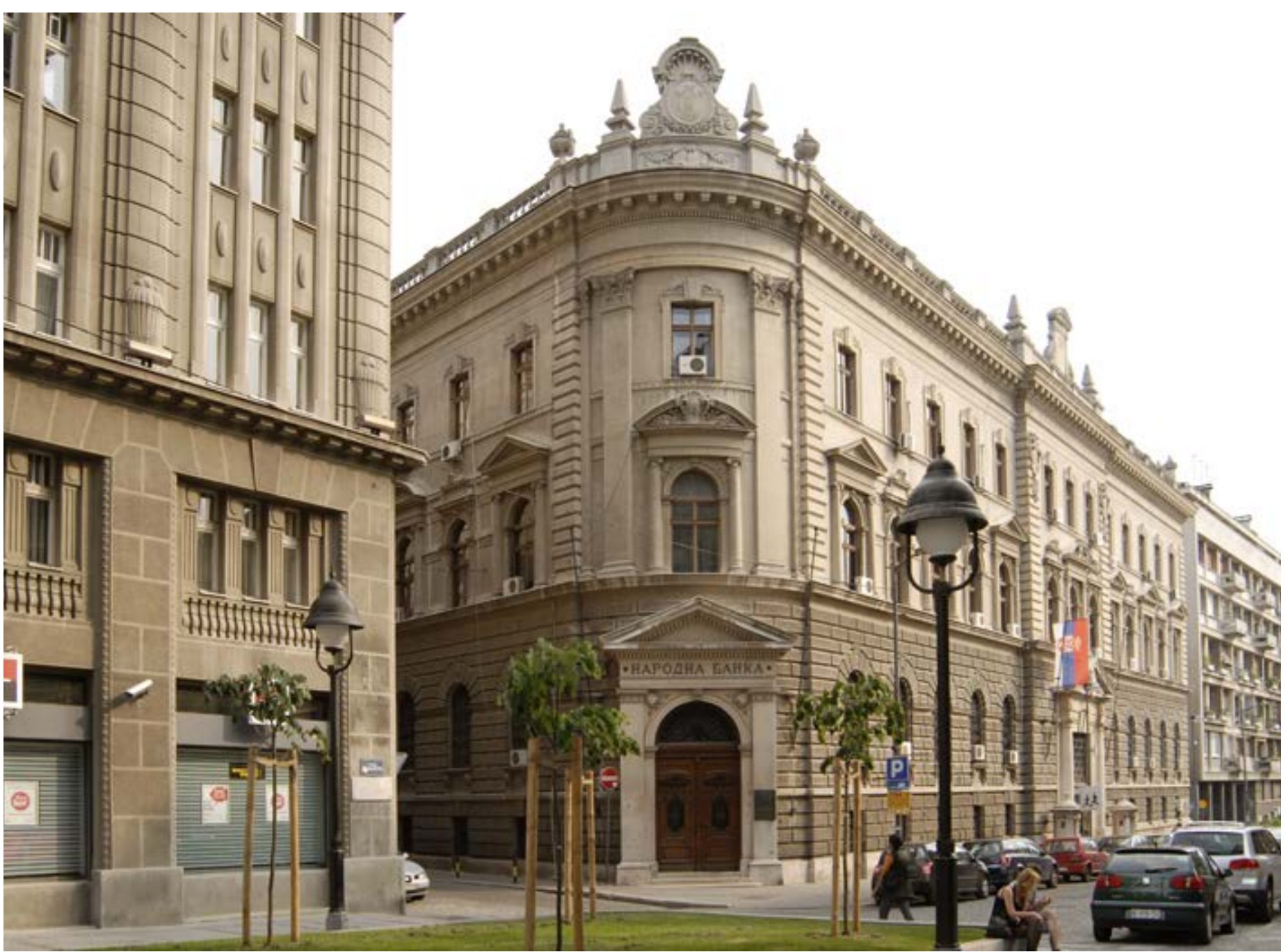

Сл. 2 / Прочеље Нароgне банке.

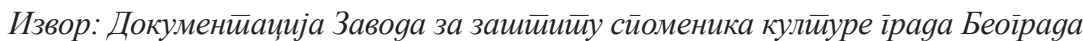

заправо представља прве форме данашњих банака. Фасада је подељена на три зоне. Приземни појас рустично је обрађен у односу на друга два чији су зидови чисти и равни. Читав објекат наткривен је балустрадом. У спољашњем третману грађевина је подвргнута строгој симетрији, а репрезентативно изведеним улазом изражена је важност институције. Угаона фасада је најистакнутија и на њој је наглашен вертикални систем. Монументални улаз заузима читаву зону рустике и фланкиран је пиластрима који носе ентаблатуру с троугаоним тимпаноном. Прозори су фланкирани пиластрима коринтског реда са сегментним тимпаноном изнад. Једино се разликује прозор над главним улазом, чији је сегментни тимпанон пресечен медаљоном. ${ }^{20}$

У накнадној доградњи Јовановић се трудио да задржи стилско јединство саме грађевине па тако, осим у основи, етапност није видљива и спољашњост је об- рађена на исти начин као и првобитно. Накнадним интервенцијама зграда је добила још једну свечану дворану и улаз на истакнутом централном ризалиту. Ризалити и углови објекта акцентовани су ивичним квадерима у спратним појасевима. Изнад кровног венца налази се атика, богато пластично обрађена, која држи вертикалност фасаде у односу на њену хоризонталну поделу.

Декоративне зоне су складно изнијансиране, а објекту је својствен и декоративни низ сачињен од прозорских и међупрозорских елемената првог спрата - у хоризонтали. Међусобним надовезивањем они се спајају у јединствени фриз, што се као мотив не појављује ни на једном другом његовом објекту. То показује Јовановићев смисао за органско надовезивање мотива у једну целину. Контраст овом збијеном декоративном низу првог спрата даје чиста површина

13 HACJE施E 


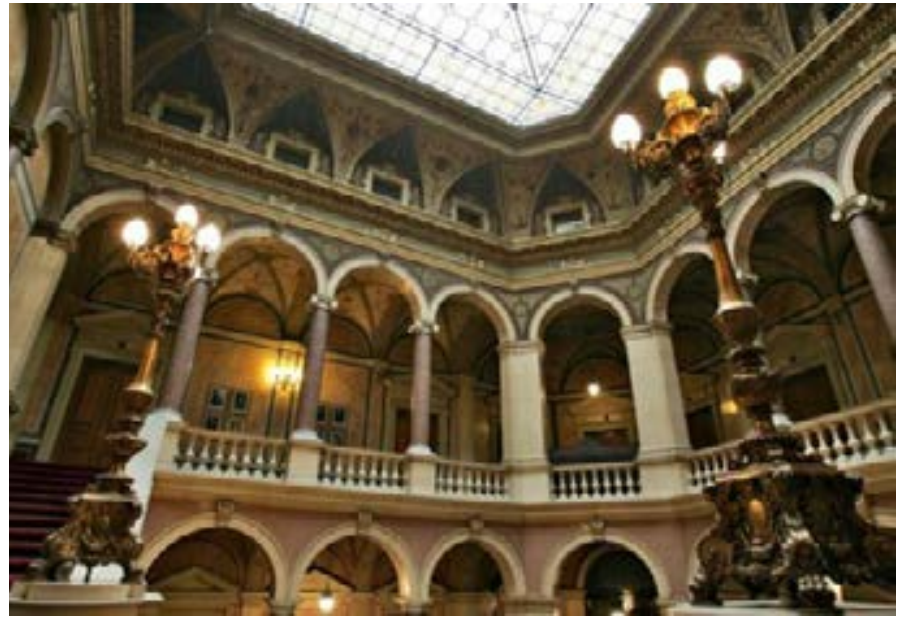

Сл. 3 / Ениееријер Нарояне банке

Извор:http://www.politika.rs/sr/clanak/228141/Ekonomija/EKPredlog-zakona-ugrozava-nezavisnost-Narodne-banke [26. 2. 2017]

наредног спрата. Дискретно наглашавање средишњег ризалита, централног прозорског отвора и главног портала условило је изванредну складност с целином. Повољном изгледу зграде доприноси и чињеница да нема јако истурених ренесансних завршних венаца, који су за њега карактеристични. ${ }^{21}$

Може се закључити да је Јовановић водио рачуна о намени зграде, али и о њеном окружењу. Успео је да избегне непотребна пренаглашавања, а да у исто време задржи све оне елементе који га чине академичарем више класе. Вешто и уз најмање средстава, постигао је максимум монументалног израза. Све је складно изведено и нема нарушавања околине. Објекат се адекватно уклопио у амбијент јер се у близини такође налазе банке, чиме се додатно истиче важност простора у којем се налази.

Изграђени део прве етапе је у суштини дијагонално сажети тип. За целокупну основу карактеристично је једнотрактно низање просторија у затвореном блок-систему са унутрашњим двориштем и испресецаним везним трактовима. Класичне пуне зидове и засвођене таванице придружује новим конструкцијама пуних и решеткастих гвоздених носача у које је уклопио и стаклене површине.

Унутрашња обрада је по величајности равна оној на спољној фасади. Сједињавање архитектуре, скулптуре и сликарства главна су обележја ове грађевине. Утисак просторности постигнут је орнаменталним детаљима и пиктуралном полихромијом. Уметничка обрада унутрашњих просторија садржи украсне и функционалне предмете примењене уметности и занатства па тако чини нераздвојну целину са архитектуром

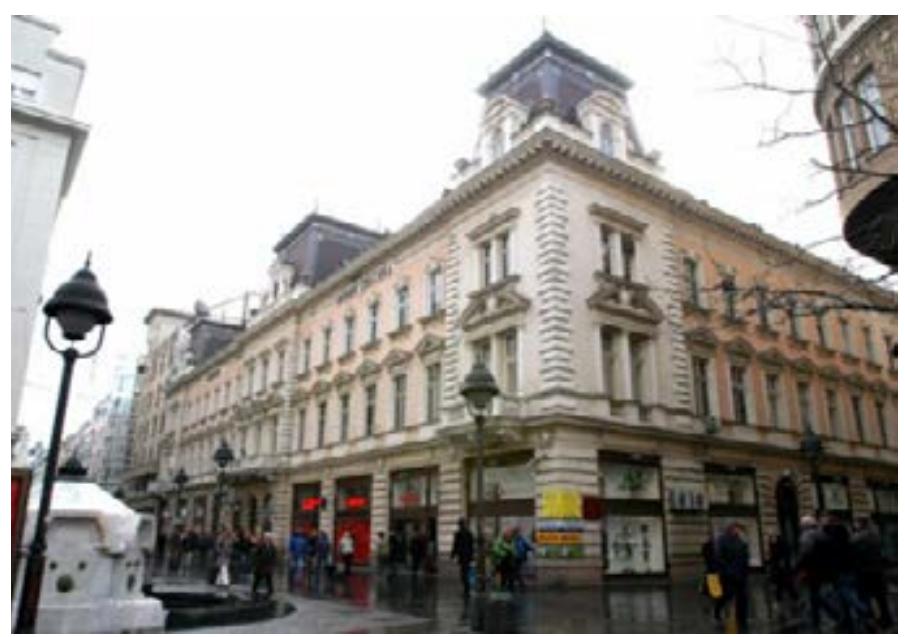

Сл. 4 / Заяужбина Николе Сйасића

Извор: http://spomenicikulture.mi.sanu.ac.rs/spomenik.php?id=712 [26. 2. 2017]

зграде. Посебно је наглашена обрада функционалних чворишта, вестибила у старом делу објекта и шалтер-сала у новом делу. Њихова композициона схема почива на контрастирању пуних и празних површина, мирних једнобојних и полихромних детаља, као и на богатој примени флоралне орнаментике и алтернацији разнородних материјала. Сликана декорација зграде прати европске токове XX века и у потпуности је подређена архитектури. Оваква врста декоративног сликарства не носи ауторски печат већ је рађена по декоративној схеми која потиче из средње Европе. Иконографски избор мотива базиран је на слободном преузимању цитата из различитих митологија и ликовних традиција. Симболика декорације, прикази рогова, сфинги, грифона, Меркура јасно указују на функцију објекта, односно реферишу на идеју успеха, богатства и благостања. Од ових важних уметничких остварења требало би издвојити и бисту Србија вајара Ђорђа Јовановића која се налази у вестибилу старијег дела објекта, а првобитно је изведена за потребе Споменика косовским јунацима у Крушевцу. ${ }^{22}$

Задужбина Николе Спасића пример је угаоног интерполирања. Ова стамбено-пословна двоспратница налази се на углу Кнез Михаилове и Јакшићеве улице и сложене је просторне структуре. У време када је подигнута (1889) представљала је значајну новину у Београду. У приземљу је имала локале, а на првом и другом спрату станове. Сам положај зграде омогућио је репрезентативно обликовање фасаде на чијем се врху налазе три кубета квадратне основе. Припадала је имућном трговцу и београдском задужбинару Николи Спасићу, а данас је то споменик културе и кул- 
турно добро од великог значаја за Републику Србију. Грађевина има неправилан и сложен облик основе са два издужена улична корпуса различите дужине, с ризалитима на уличним фасадама и наглашеним углом, и са дворишним крилима и степенишним вертикалама са дворишне стране. ${ }^{23}$ Припада типу угаоних зграда које су са две стране биле на уличној регулацији и својим фасадама, односно с два прочеља и најчешће посебно обликованим угаоним делом, издваја се у односу на суседне зграде и истакнута је као доминантни урбани мотив околног окружења. ${ }^{24}$

Након српско-турског и бугарског рата настаје нов импулс грађења који неће јењавати све до 1914. године. Ово доба одликује се знатно солиднијим радом, масивним зидовима, обрађеним занатским детаљима столарије, браварских и лимарских радова. Нарочито се проучава архитектонски детаљ. Обликовање је устаљено, а Београд је прихватио ренесансу, понегде китњасту и са барокним прелазима. Обрада спољних површина обавља се у малтеру и постаје пластична. У ентеријеру, улазима и собама израђују се пиластри и венци, а ни полихромија није заборављена. Архитекти који предводе овај талас били су образовани Срби који су студирали у Бечу, Минхену, Берлину и Пешти - Александар Бугарски, Светозар Ивачковић, Константин Јовановић. Ова Јовановићева зграда солидно је грађена, по старом принципу двотрактних основа са стакленом галеријом позади, бочним крилима, а посебна пажња посвећена је улазу и степеништу. ${ }^{25}$

Спољашњост фасаде може се сматрати примером еклектичке архитектуре. На добар начин уклопљена је симетричност ренесансе с призвуком пластичких барокних елемената. Уочљива је хоризонтална подела фасаде, при чему је посебно наглашена она која

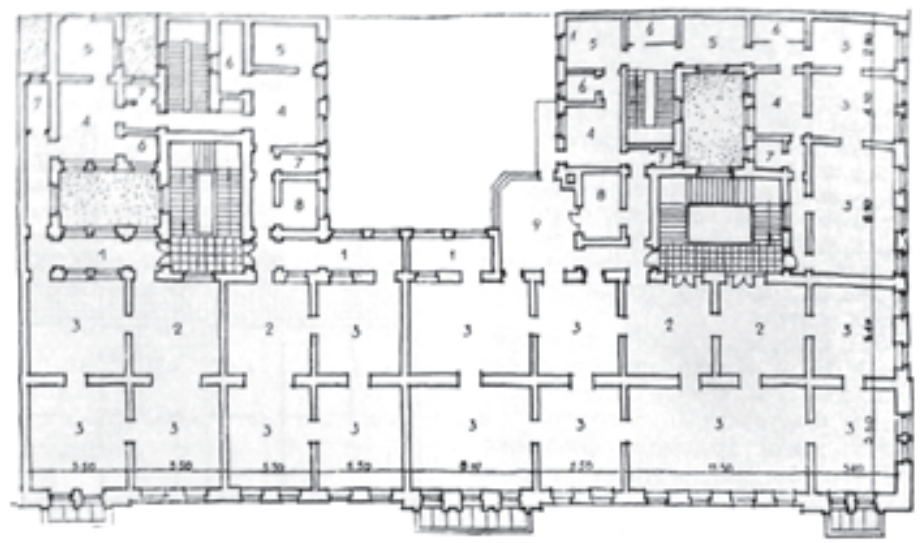

Сл. 5 / Заяужбина Николе Сйасића, основа

Извор: Нестиоровић 1955. стир. 259. носи кордонски венац. Масивност зграде разбијена је великим застакљеним површинама и сукцесивним ређањем прозорске декорације. Угаони ризалити специфични су по томе што имају балконе са балустрадом и удвојене прозоре, што није толико честа карактеристика Јовановићевог градитељства. ${ }^{26}$

Овде је до пуног изражаја дошло богато пластично моделовање и колористички контрасти с циљем да се постигне монументална академска архитектура карактеристична за тадашње европске метрополе. Ова репрезентативна стамбена палата доминирала је средишњим делом Кнез Михаилове улице у време када је изграђена. Облик њеног волумена био је чест код европских стамбених палата које су заузимале целу ширину уличног фронта, али ова задужбина није имала такву диспозицију већ је била изграђена на углу двеју релативно уских улица и била је уграђена са обе бочне стране. Налазила се окружена низовима нижих једноспратница, изграђених у претходне две деценије, а простор некадашње Краљеве баште (место касније изграђене Краљевске академије) био је празан тако да је њена архитектура доминирала простором око Делијске чесме и слободно се сагледавала из правца Калемегдана. Доминантан мотив зграде је средишњи ризалит који својом ширином и висином, као и репрезентативном обрадом, наглашава симетричност укупне композиције и сам улаз у зграду. Спратни делови прочеља осмишљени су као јединствена површина, од међуспратног венца до завршног кровног венца. Класично академско обликовање уобичајено за велике државне палате примењено је на великој вишепородичној стамбеној згради, са сложеном просторном структуром која је представљала значајну новину за Београд. Зона приземља третирана је као снажан базис тако да има наглашене широке и дубоке хоризонталне спојнице. У приземљу су три отвора на средишњем ризалиту завршена лучно и истакнута радијалним спојницама, док су остали отвори, излози дућана, већих димензија и правоугаоног облика. Улазни портал има богато профилисана дрвена двокрилна врата са декоративном решетком на надсветлу. Површине спратова су глатко малтерисане уз наглашавање ивица ризалита имитацијом камених квадера са закошеним рубовима. Између приземља и спратног дела је парапетни појас који повезује отворе првог спрата и јасно одваја ове две зоне различите намене, јавне и приватне, што је такође у духу ренесансног градитељства.

Доследна примена академских образаца приметна је и у обради првог спрата (piano nobile). Отвори на средишњем ризалиту су полукружно завршени и уоквирени класичним неоренесансним едикулама с 
јонским полустубовима и сегментним тимпанонима. Нешто су богатије изведени отвори на два бочна ризалита, чиме је успостављена хармонична уравнотеженост целине. Они су фланкирани јонским полустубовима и повезани заједничким сегментним тимпаноном, испуњеним декоративним медаљоном. Отвори првог спрата на свим ризалитима додатно су наглашени масивним балконима на декоративним конзолама и оградом с постаментима и балустрадама. Остали отвори овог спрата имају једноставно профилисане неоренесансне оквире с троугаоним тимпанонима. Отвори другог спрата такође су у духу академских правила, али с нешто скромнијим моделовањем. Обе уличне фасаде завршавају се снажно избаченим и богато моделованим неоренесансним завршним венцем. Код ризалита, изнад кровног венца уздижу се атике с постаментима и вазама на угловима и полукружно завршеним таванским прозорима у средини. Репрезентативна обрада улазног вестибила, ходника и пространих степенишних простора појачава утисак богатог обликовања. Зидови улазног вестибила рашчлањени су коринтским пиластрима, архиволтама, профилисаним венцима, медаљонима и другом декоративном пластиком, а површине између њих су осликане. ${ }^{27}$

Кућа Драгомира Радуловића у Улици Вука Караџића такође је пример угаоног интерполирања, приватне намене. Њена основа решена је на исти начин као и Задужбина Николе Спасића, дакле поседује сложену основу са издуженим уличним корпусима и наглашеним углом. Приступни ходници били су приближно у средини једног од уличних корпуса, док је степенишна вертикала била у дворишном тракту, у равни дворишне фасаде, са бочне стране ходника. ${ }^{28}$ Припада групи једнотрактних грађевина, једноспратница такође пословно-стамбене намене са унутрашњим двориштем. Зидне површине су обрађене отворима веће површине, што представља савремен приступ, тако да су зидне масе код приземног дела сведене на ступце с пластично истакнутим пиластрима. Улазни портали за стамбени простор на спрату засведени су полукружним луком. Фасада спратног дела рашчлањена је на поља с једном осовином отвора, с тим да су површине бочних ризалита наглашене хоризонталним спојницама, док су површине широког средишњег поља глатко малтерисане и оживљене класичним подеоним пиластрима. Главна фасада рашчлањена је бочним ризалитима и централним делом, у чијем се подножју налази репрезентативни улаз који је фланкиран рустикованим пиластрима. Прозори су оивичени канелурама, а изнад њих, на конзолама, почивају тро-

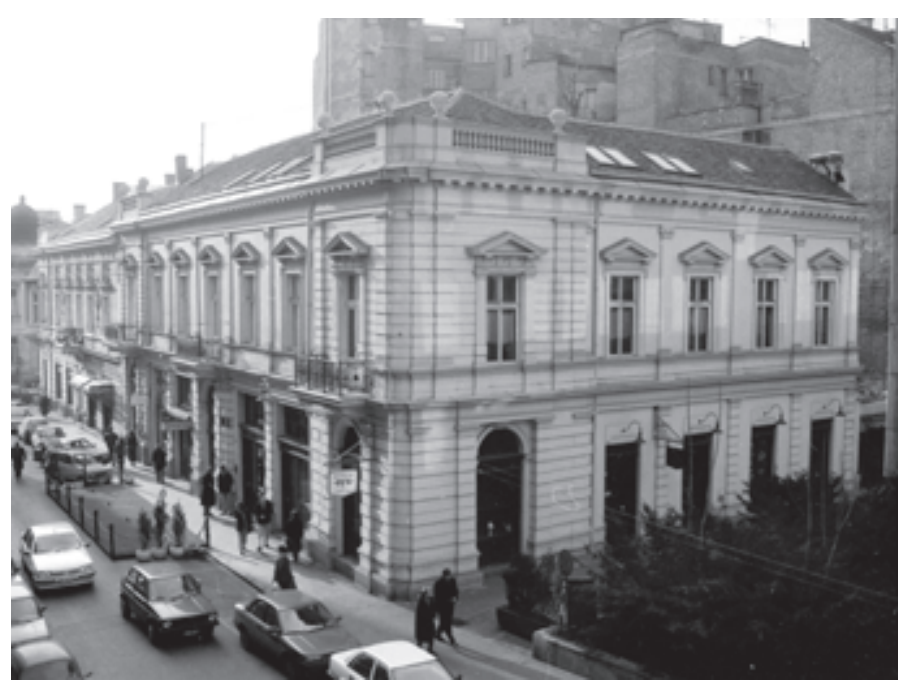

Сл. 6 / Кућа Драїомира Раяуловића, уїао Вука Каращића и Делијске улице (фотиоїрафија ауйора). Извор: Докуменйаиија Завоgа за зашииийу сиоменика кулйуре ірраgа Беоїраgа

угаони тимпанони који су завршени триглифима и метопама. Занимљив је податак који износи Иван Клеут о мотиву тимпанона који се налази над отворима ризалита. Реч је о хоризонтално завршеним тимпанонима који се, поред овог објекта, срећу још и на спратним прозорима ризалита куће Марка Стојановића у Кнез Михаиловој улици, као и на угаоном отвору старе зграде Београдске задруге из 1888. године. Према томе, такви мотиви могу послужити датовању ових објеката, за које Клеут истиче да су само једна од особености Јовановићеве архитектуре из првих година његове градитељске делатности у Београду. Сходно томе, ова зграда датује се око 1885 . године. ${ }^{29}$

Прозори на спрату одвојени су јонским пиластрима, што је још једна одлика првих Јовановићевих дела, будући да ће се они наћи још једино на фасади Стојановићеве куће према Париској и Рајићевој. Због локације на којој се налази, објекат је изведен нешто скромније у односу на претходне, који се налазе у прометнијим улицама. На овој згради изостављени су угаони кубети због умерености објекта и усклађивања са околином и у том сегменту је приметно Јовановићево уважавање затеченог простора. Грађевина је усклађена са околином како стилом тако и висином. Може се рећи да је и овде извршен метод прилагођавања уз изузетно уважавање постојећег урбанистичког склопа.

Кућа Косте Миленковића пример је интерполираног објекта у низу. Налази се у Змај Јовиној улици број 9 и изграђена је око 1900. године. Према положају на парцели, односу према улици и суседним зградама, односно величини и облику саме парцеле и ње- 


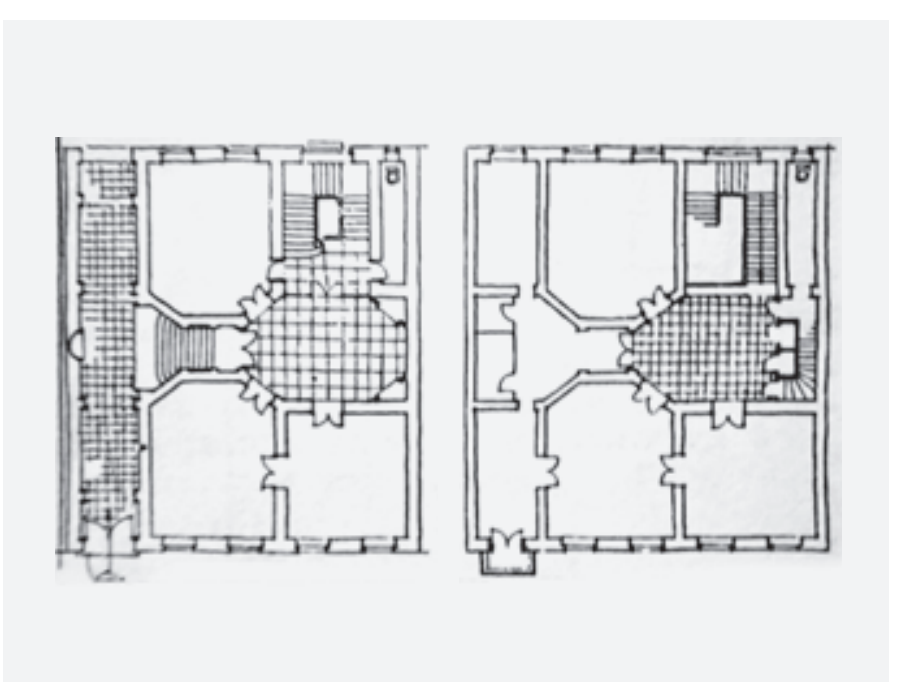

Сл. 7 / Приземље и сиррат куће Костее Миленковића, Годишњак Музеја їраgа Беоїраgа, Нестиоровић 1955, кн. 2, сими. 260.

ног положаја у оквиру градског блока, основа ове куће припада типу куће изграђене на регулационој линији улице. Обострано је уграђена у целу ширину парцеле, тако да је улаз у зграду био на главној уличној фасади, а унутрашњи простори су им били оријентисани ка улици и дворишту. Изграђена је у најужем градском језгру, а њен правоугаони облик основе био је чест и код других обострано уграђених зграда подигнутих крајем XIX и почетком XX века, код којих су примењиване академске схеме настале на традицији класичне ренесансне архитектуре. Ова кућа има релативно малу једноставну основу, скоро квадратног облика.

Стамбене просторије (у приземљу и на спрату) обухватају хол са две стране, с треће стране су пространо степениште и уска помоћна просторија, а четврта страна хола је прислоњена уз бочну страну парцеле. Специфичност овог решења је да су две собе лоциране у угловима квадратне основе и имају засечени угао с вратима, ка холу, што директно асоцира на основе оријенталног плана. ${ }^{30}$ Број отвора у приземљу и на спрату (5) условио је асиметричну композицију зграде која је још додатно истакнута постављањем улазног портала са бочне стране. Асиметричан положај портала нарушавао је усклађеност академске композиције, поготово ако је изнад њега био и балкон, као што је то случај са овом кућом. Јовановић и даље доследно примењује традицију складног и прецизног неоренесансног обликовања. На прочељу су примењени стилски елементи и пластична декорација инспирисана градским палатама римске високе ренесансе. Наглашена је хоризонтална подела на рустич-

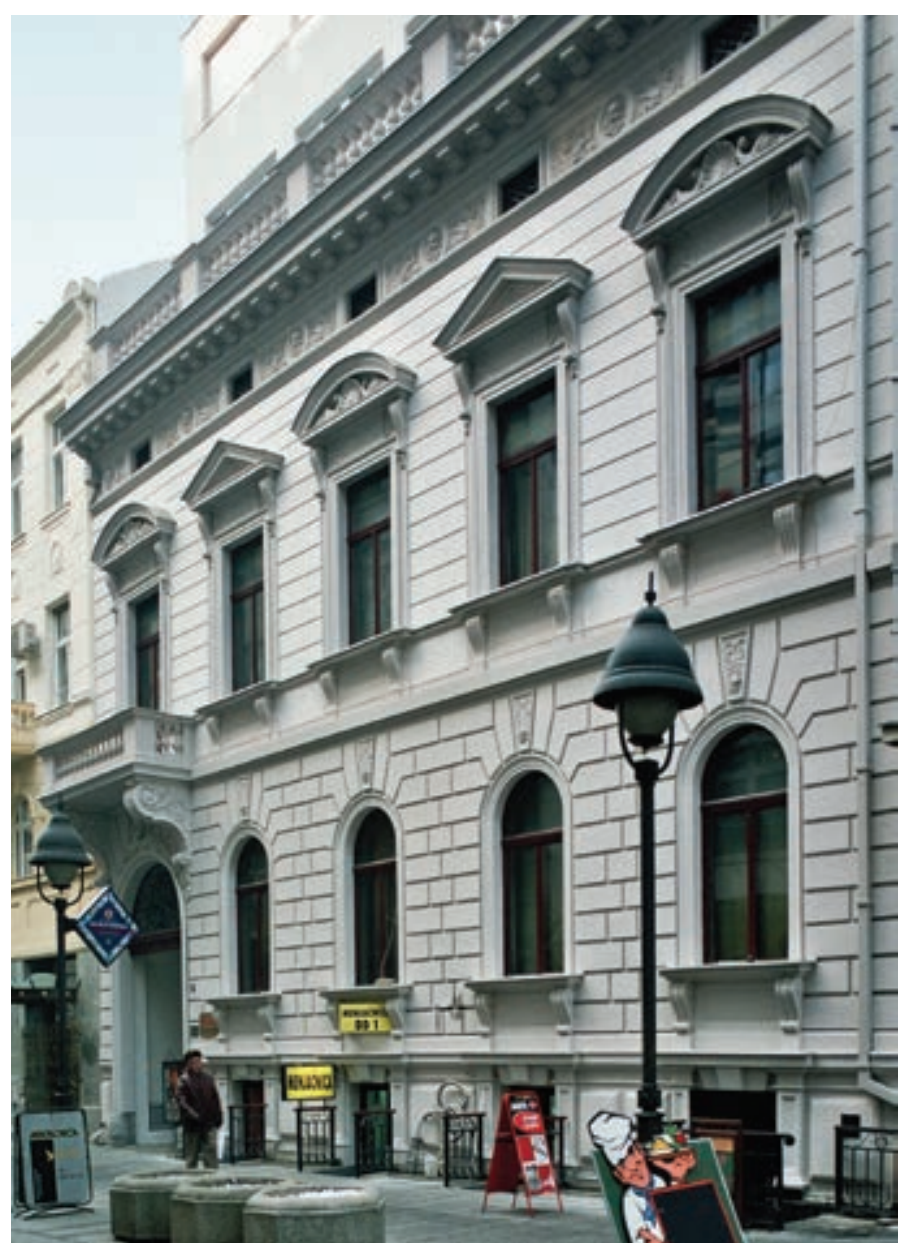

Сл. 8 / Кућа Костие Миленковића. Извор: Докуменйаиија Завоgа за зашииийу сйоменика кулйуре їраgа Беоїраgа

но обрађен приземни део и богатије моделован спрат уз доминацију хоризонтала које су видљиве у подеоним венцима, избаченом кровном венцу и атици. Иако су сви отвори симетрично и ритмично распоређени, бочни асиметричан положај високог улазног портала означавао је мало одступање од уобичајених схема с наглашеном централном осом симетрије и показивао је тежњу ка постизању веће динамичности и сликовитости прочеља. Велики улазни портал и масивни балкон најупечатљивији су мотиви прочеља који свакако привлаче око посматрача, док су остали елементи складно моделовани. Прозори у приземљу завршени су полукружним луком и уоквирени профилисаним оквиром. Испод прозора налази се избачена потпрозорна гредица коју носе велике вертикалне конзоле с волутама, што представља одлику ренесансних палата. Спратни прозори имају такође потпрозорне гредице и конзоле, изнад којих се налази прозорски отвор уоквирен профилисаним оквиром и надвишен троугаоним или сегментним тимпаноном на витким верти- 


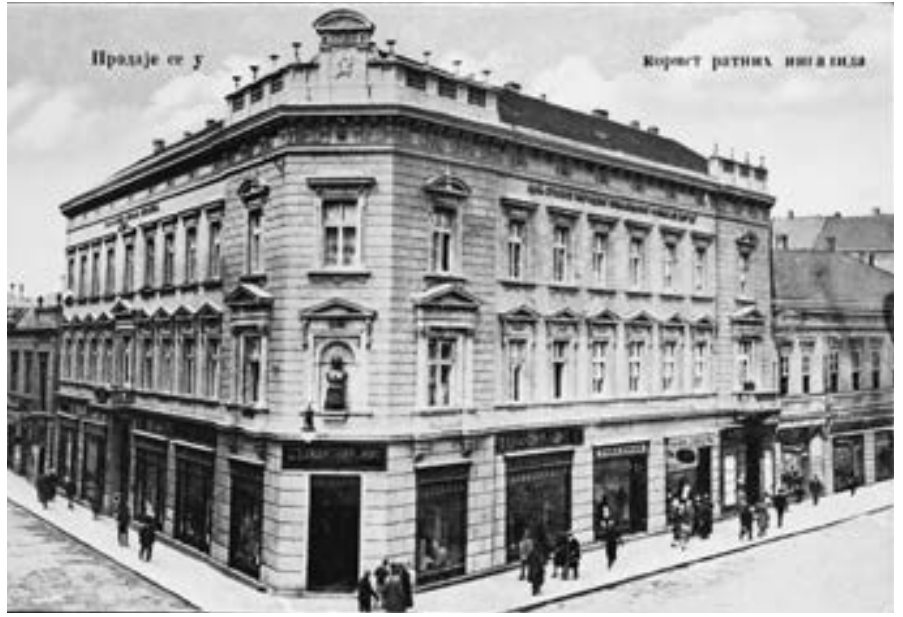

Сл. 9 / Кућа Јована Панђеле. Извор: Докуменйащија Завоgа за зашииийу сиоменика кулйуре їраgа Беоїраgа

калним конзолама. ${ }^{31}$

Овај период показује значајне промене у односу на претходне Јовановићеве објекте. Сада једноспратне породичне куће добијају нов концепт утемељен на примеру Земперове Опенхајм палате у Дрездену, где је остварена извесна нота отмености и софистицираности. Кућа Косте Миленковића је тротрактна грађевина коју чине подрум, високи партер и спрат. Спољашњу фасаду чине две зоне раздвојене кордонским венцем. Изнад лучно завршених прозора у приземној зони налазе се прозори правоугаоног облика са богато украшеним сегментним и троугаоним тимпаноном. Главни улаз у зграду завршен је полукружно са богатим флоралним мотивима и постављен је с леве стране фасаде, чиме се нарушава класична академска симетрија којој је Јовановић тежио у својим ранијим делима и успоставља се динамичка вертикала. Изнад улаза налази се балкон са балустрадом. У кућу се улази преко импресивне богато дрворезбарене колске капије са детаљима браварије јединственим у архитектури тог времена, на којој се истиче монограм власника. Зидови пролаза су богато обрађени штуко декорацијом. Монументално камено степениште фланкирано полукружним нишама и дрвени богато резбарени портал водили су у раскошан ентеријер којим доминира степениште од кованог гвожђа изузетне уметничко занатске обраде. Цео ентеријер је стилски доследно изведен. ${ }^{32}$

То је кућа која припада новом типу, централном, по угледу на распореде немачког класицизма, који је црпео своје примере из стамбених зграда Паладијевих основа. Сада се напушта раније двотрактно решење и основа, која остаје симетрична, добија три тракта где се око централног вестибила решава цео распоред стана. ${ }^{33}$

Кућа Јована Панђеле пример је надградње. Налази се у Кнез Михаиловој улици број 37 и реч је о згради која је била завештана Инвалидском фонду „Свети Ђорђе“. Овај објекат настао је најпре по плановима чувеног архитекте Александра Бугарског (18351891), за месара Јована Панђелу. Након његове смрти, наследници су зграду продали Николи Спасићу, који ангажује Јовановића за надградњу још једног спрата. Сама зграда пројектована је као угаони објекат с мотивом засеченог угла. ${ }^{34}$ Пажљивом надградњом Јовановић се трудио да свој део прилагоди оригиналном изгледу зграде и да третман новог спрата прати фасадну обраду нижих нивоа. Постојећој структури додао је три балкона, на свакој страни засеченог угла по један. Затим је уклонио оригинални поткровни фриз и атику са украсним вазама. Изнад прозора са степенастим прозорским оквиром поставио је профилисане гредице на конзолама, док прозори бочних делова угла имају преломљене сегментне тимпаноне. Атика изнад кровног венца добила је едикулу са сегментним тимпаноном и на тај начин је успостављена вертикална линија

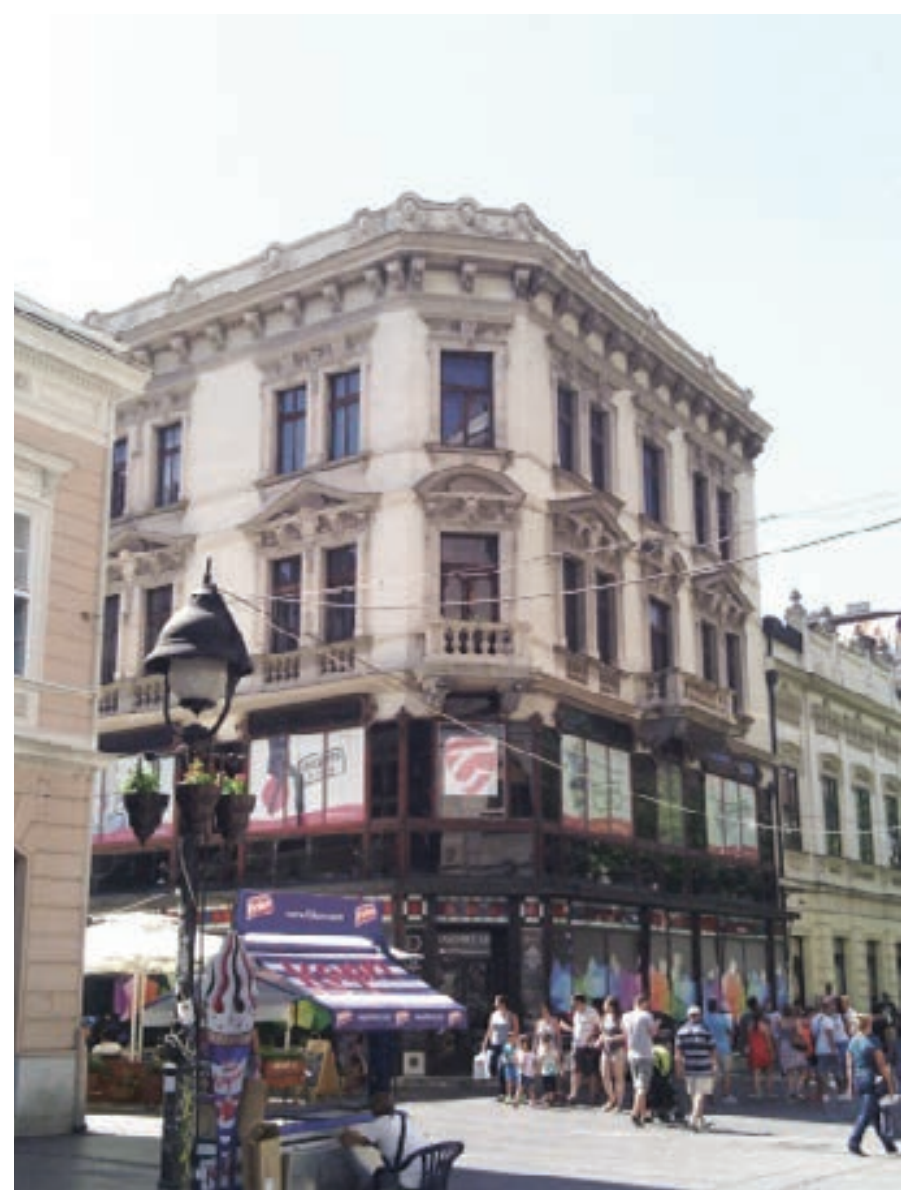

Сл. 10 / Кућа Димитирија Живауиновића (фойоїрафија ауйора) 
угаоне фасаде. ${ }^{35}$ Данашњи изглед потиче из година после Другог светског рата, када је зграда надзидана са још два спрата. ${ }^{36}$ Оваквим приступом Јовановић је показао изузетну прецизност и умешност у пројектовању, притом задржавши архитектонску складност грађевине и стилску особеност старијег нивоа.

Кућа Димитрија Живадиновића је пример угаоног типа интерполације, с мотивом засеченог угла. Налази се на углу Кнез Михаилове 41 и Ускочке 2 и подигнута је 1912. године. Изграђена је с намером да буде прва робна кућа у Београду, а позната је још и под називом Робна кућа „Митић“, по њеном власнику који је у њој становао од 1919. до 1941. ${ }^{37}$ Двојна намена зграде истакнута је и фасадном обрадом. Доњу зону чине прозорски отвори различите етажне декорације, док су горња два спрата обрађена равно, с наизменично постављеним редовима прозора. Обраду угаоног дела зграде чине удвојени прозори подведени под заједничке натпрозорске елементе. Поткровни фриз конзола носи профилисани кровни венац који се завршава балустрадом. Како је грађевина била од почетка намењена за робну кућу, неопходни отвори у приземном појасу су у складу са захтевима времена урађени од гвоздених профила са декоративним сецесијским елементима уместо дрвених рамова, како је то Јовановић до тада и пројектовао. ${ }^{38}$ Фасадни део доње зоне није обрађен малтерним спојницама нити су у том делу могли постојати тимпанони са богатом пластиком, онако како је Јовановић то замислио. Употреба сецесијских елемената није одговарала његовом укусу, иако је и она произашла из широког спектра историјских стилова. Главни мотив је јако засечен угао којим доминира балкон првог спрата. Фасада је степенована по хоризонтали уз богату примену пластичне декорације у тимпанонима прозора и атици над кровним венцем. Поред Задужбине Николе Спасића и куће адвоката Марка Стојановића, зграда Димитрија Живадиновића представља још једно Јовановићево остварење које доприноси архитектонском значају Кнез Михаилове улице. ${ }^{39}$

Љиљана Бабић наводи да је ово нешто мање успешна грађевина судећи по пропорцијама и детаљима. Она истиче да Јовановић овде није у довољној мери савладао односе рустичног дела доњих етажа према горњим, као и њихове односе према стакленим површинама намењеним за продавнице. Засецањем угаоног дела целом висином објекта није постигнут жељени ефекат, нарочито не са угаоним балконом као додатком. Чини се да је Јовановић на претходној згради у Змај Јовиној 9 показао већу умешност приликом изградње балкона. ${ }^{40}$

Кућа својим стилским карактеристикама потпуно одговара околини и због тога се може рећи да је при- мењен метод прилагођавања, а сама зграда доприноси значају Кнез Михаилове улице у којој се и налази. Ипак, приметно је њено истицање и висинско одударање од осталих објеката у окружењу. То се може објаснити ако имамо у виду да је она од самог почетка била конципирана као троспратница двојне намене, као робна кућа папирне индустрије и као објекат за становање. Њеном висином нису нарушени склад и хармонија амбијента будући да она није једини објекат који својом висином прелази замишљену висинску хоризонталу.

Куће Марка Стојановића - Прва грађевина изведена у Београду по пројекту Константина Јовановића била је кућа Марка Стојановића, адвоката и вицегувернера Народне банке, у Кнез Михаиловој улици број 53-55. Реч је о једноспратној грађевини двојне намене подигнутој око 1885 . године.

Представља тип куће изграђене на углу, лоциране на пресеку двеју улица, која једним углом заузима целу ширину парцеле тако да је била обострано уграђена у део континуалног уличног фронта. Улаз у зграду био је са улице, на једној од две уличне фасаде, а унутрашњи простори били су оријентисани ка улицама и дворишту. Њена основа је компактног облика, с ризалитима на углу и светларницима. Репрезентативан стан на спрату има седам соба које се нижу у два улична тракта и бочном тракту. Собе са три стране обухватају пространо правоугаоно предсобље, а са четврте стране је двотрактно двориште. На спрату суседне зграде у Кнез Михаиловој 55 централни простор је дводелан и чине га улазни вестибил с репрезентативним трокраким степеништем и предсобље квадратног облика. Седам соба у низу окружује централни простор са три стране, а са четврте стране, ка бочном суседу, налазе се једна соба и светларник.

Припада типу угаоних интерполација, али за разлику од осталих његових угаоних грађевина ова је специфична из разлога што с њом започиње читав блок који је овог пута омеђен Рајићевом, Париском и Кнез Михаиловом улицом. Објекат чине две спојене целине сличних неправилних основа решених у три тракта. Репрезентативност зграде постигнута је обликовањем фасаде, уз примену свих академских начела. Фасада у Кнез Михаиловој улици изражена је и због тога што се на њеним угловима налазе балкони с кубетима на октогоналној основи. Спољашња равнотежа фасаде успостављена је усклађеношћу хоризонталних и вертикалних елемената. Због велике дужине уличних прочеља примењена је трочлана симетрична вертикална подела са избаченим пољима, ризалитима, са бочних страна. Наглашена је хоризонтална подела на зоне приземља и спрата, између 


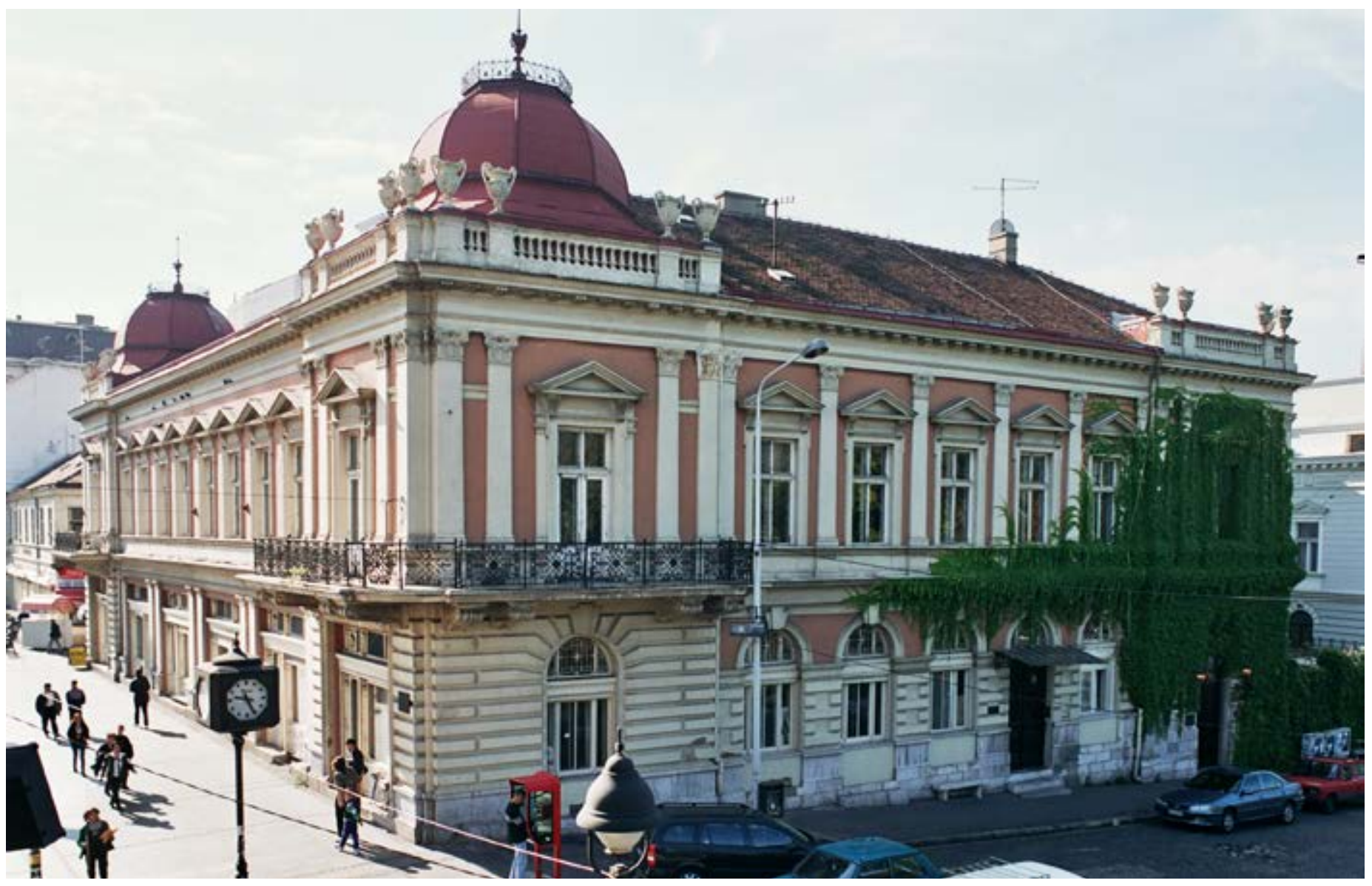

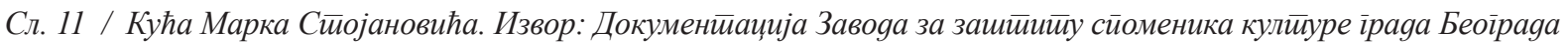

којих је парапетни појас који повезује спратне отворе. Отвори у приземљу се постепено увећавају тако да формирају веће правоугаоне излоге, између којих су рустично обрађени ступци са удвојеним пиластрима. Површина спратног дела је глатко малтерисана. Парапетни појас је такође глатко обрађен. Кровни венци имају сложену класичну профилацију са глатко обрађеним фризом без декорације и са конзолицама испод завршног венца. Ризалити у приземљу имају снажнију рустичну обраду, са широким и дубоким спојницама закошених ивица. Обрада спратног дела ризалита је са удвојеним коринтским пиластрима дуж бочних ивица. Целом ширином ризалита су балкони са снажним конзолама у облику волута, чије су ограде лаке, од веома декоративно обликованог кованог гвожђа. Посебно репрезентативна прочеља, која су се пружала између двеју улица, добијала су изнад угаоних ризалита куполе на полигоналним основама, по узору на италијанске барокне примере. Улази су завршени полукружним луком и имају полукружне профилисане архиволте и веома лепо профилисана дрвена крила изнад којих је застакљено полукружно надсветло са декоративном гвозденом решетком. ${ }^{41}$
Заједно са овом, морамо посматрати другу кућу Марка Стојановића која се налази у непосредној близини ове, у Париској 15. Саграђена је касније, 1900. године, и заједно са првом чини амбијенталну целину и део урбаног склопа. Ова кућа припада једнострано уграђеном типу који има само једну бочну страну, где је био бочни пролаз из којег се улазило у зграду. Ова породична кућа има габарит у облику неправилног правоугаоника са закошеним бочним странама, што је произашло из облика парцеле (њена бочна ивица је закошена, а зграда је паралелна с правцем улице). Припада типу куће подужног плана са двотрактним решењем. У основи има бочно постављен улазни вестибил (у тракту ка улици) и степениште (у тракту ка дворишту), док остали простор приземља (у оба тракта) заузимају пословни садржаји. На спрату је степенишни простор само са бочне стране дворишног тракта, док остали простор заузимају стамбене просторије. У сутерену је слично решење, али с помоћним просторијама. ${ }^{42}$ Пројектована је на начелима Земперове Опенхајм палате у Дрездену. ${ }^{43}$ Основа куће је неправилног облика и осмишљена је као двотрактно решење. Основа је решена бочно поставље- 
ним улазним вестибилом ка улици и степеништем ка дворишту. Спрат је конципиран као piano nobile са стамбеним просторијама, а у сутерену су помоћне просторије. Главна фасада ка улици решена је системом прозора са декоративним отворима, а симетричност је разбијена постављањем репрезентативног портала на левој страни фасаде, ближе дворишту. Он је декоративно обрађен и чине га два дорска пиластра која носе полукружни тимпанон на средини пресечен декорисаним барокним медаљоном. Фасада окренута ка дворишту решена је на сличан начин као и главна, с том разликом што су ритмови прозорских отвора скромније обрађени. Читава фасада одликује се рустичним приземљем и мирнијом обрадом на спрату, чију поделу истиче профилисани венац. Хоризонталност се додатно наглашава лучним прозорским отворима у приземљу, а на спрату алтернацијом архитравних прозора с полукружним и троугаоним забатом. ${ }^{44}$ Симетрију је поново постигао постављањем балкона и медаљона у луку централног спратног прозора. Декоративност је изведена од кованог гвожђа једнаког квалитета као и на првој кући. Однос ширине и висине фасаде је у савршеном односу 1:1. Кућа је изведена у стилу италијанске ренесансе, а два барокна медаљона изнад портала и централног спратног прозора наглашавају еклектични концепт. ${ }^{45}$ Сам објекат врло добро се уклапа у амбијент и својом умереном и складном фасадном обрадом не ремети мир околине. Нема пренаглашених детаља који би привлачили пажњу, већ је успостављена обострана хармоничност, како самог објекта, тако и парка ка којем је окренут.

Задатак архитекте није се састојао само у томе да произведе утисак монументалности и декоративности, већ и интиме породичног дома, који би се уклапао у шири архитектонски амбијент. Монументалност је већ била наглашена на првој кући Марка Стојановића. Скрећући из Кнез Михаилове у Париску улицу, која директно комуницира с Калемегданским парком, било је потребно начинити мирнији концепт и усагласити га с таквом архитектонско-парковском матрицом. Амбијентална вредност ове зграде је у корелацији с првом кућом Марка Стојановића, као и са зградом у Париској 16, са којима чини целину стилски и хронолошки дефинисану. Корелација је постигнута не само стилском уједначеношћу већ у највећој мери сагласношћу појединих архитектонских мотива заједничких за обе куће Марка Стојановића. Од секундарног значаја је и амбијентална целина коју чини блок у којем се зграда налази, а који је готово у потпуности стилски и хронолошки хомоген. Од посебне важности је релација фронта блока и парка Калемегдан. Ниједна зграда у поменутом блоку, осим прве куће Марка Стојановића, архитектонском концепцијом није искакала из концепата мирних и хармоничних фасада, без наглашене монументалности. Ова здања сведоче о високим стандардима које је једна млада држава на преласку из XIX у XX век поставила себи као идеал, а то је да прими и асимилује европске утицаје и да од Београда за врло кратко време направи метрополу по европским узорима.

\section{Душица Љ. Николић,} историчар уметности Београд dusican93@gmail.com

\section{НАПОМЕНЕ:}

1] Поред математичког поступка, реч интерполација - од лат. interpolatio, односила се испрва само на уметање речи, фраза и реченица у књижевни текст. У грађевинарству подразумева изградњу објеката између већ постојећих. Према: Клајн и Шипка 2008.

2] Истио

3] Премерл 1983: 70-75.

4] Полак 1983: 33.

5] Филиповић 1983: 42-45.

6] Мароевић 1986: 189-251.

7] Нав. вело: 210 .

8] Истио: 216 .

9] Кадијевић 2013: 243-258.
10] Иванчевић 1983: 82.

11] Кадијевић 2016: 37.

12] Истии 2009: 203, 204.

13] Нав. gело: 204.

14] Истио: 205.

15] Бабић 1960: 13.

16] Ванушић 2013: 56.

17] Нав. gело: 56.

18] Истио: 58.

19] Клеут 2006: 217.

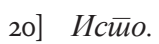

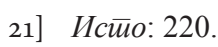


22] Бабић 1960: 13.

23] Божовић 2012: 6.

24] Ротер-Благојевић 2006: 135.

25] Нав. яело: 192.

26] Несторовић 1955: 259.

27] Клеут 2006: 237.

28] Ротер-Благојевић 2006: 275.

29] Нав. дело: 139.

30] Клеут 2006: 234.

31] Нав. gело: 111.

32] Истио: 303.

33] Гордић и Павловић-Лончарски 2001: 22.

34] Несторовић 1955: 260.

\section{ЛИТЕРАТУРА}

Алфиревић, Ђ. и Симоновић Алфиревић, С. (2015), Интерполација у архитектури: приступи пројектовању интерполираних објеката и „спона“ као интегративни елемент, Архииекӣира и урбанизам 41 (Београд): 24-39.

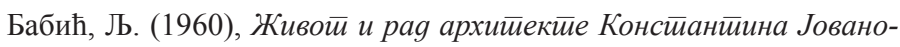
вића, у: Зборник Архитектонског факултета, књ. 6, свеска 2.

Божовић, А. (2012), Кућа Марка Стојановића, Париска 15 у Београду [интернет] доступно на http://beogradskonasledje.rs/wpcontent/uploads/2012/09/10/6_aleksandar_bozovic.pdf [26. 2. 2017], Наслеђе Х (Београд): З3СКГБ, 91-102.

Божовић, А. (2012), Нарояна банка Србије [интернет] доступно на http://beogradskonasledje.rs/wp-content/uploads/2013/06/NarodnaBanka.pdf [26.2.2017], Београд: ЗЗСКГБ.

Ванушић, Д. (2013), Констианйин Јовановић, архийекйа великой форматиа, Београд: Музеј града Београда.

Гордић, Г. и Павловић-Лончарски, В. (2001), Архииеекӣа Консйанйин Јовановић, Београд: ЗЗСКГБ.

Ivančević, R. (1983), Interpolacija: međuvrijednost među vrijednostima ili krivotvorina, u: Arhitektura 184-185, ur. Hržić, M., Zagreb: Savez arhitekata Hrvatske: 82-85.

Кадијевић, А. (2013), Интерполације - нужност и надахнуће новије београдске архитектуре, Зборник Матиице срйске за ликовне умейностии 43 (Нови Сад): 243-258.

Кадијевић, А. (2016), Палайа Милоша Савчића (1924-1926) - неииийична беоіраgска уїаона зїраgа, Наслеђе XVII (Београд): 37-51.

Кадијевић, А. (2009), Иниеерйолачије у беоіраяској новијој архи-
35] Клеут 2006: 245.

36] Нав. gело: 246 .

37] Гордић и Павловић-Лончарски 2001: 26.

38] Нав. яело: 28.

39] Клеут: 2006: 245.

40] Гордић и Павловић-Лончарски 2001: 28.

41] Бабић 1960: 28.

42] Ротер-Благојевић 2006: 269.

43] Нав. gело: 107.

44] Кућа Косте Миленковића у Змај Јовиној улици такође је имала Земперову палату као узор.

45] Исти систем прозорских отвора среће се и на кући Косте Миленковића као и на појединим објектима блока у Рајићевој 16 и 18.

иекииури. Неомовернистиичка ауйорска иниеерйолаиија у Таковској улици (2003-2008), Наслеђе Х (Београд): 203-212.

Клајн, И. и Шипка, М. (2008), 'Интерполација', Велики речник стираних речи и израза, Нови Сад: Прометеј: 532.

Клеут, И. (2006), Градитељски опус Константина Јовановића у Београду, Гоgишњак їpaga Беоїраgа (ГГБ) LIII (Београд): 213-249.

Maroević, I. (1986), Sadašnjost baštine, Društvo povijesničara umjetnosti SR Hrvatske, Zagreb: 189-251.

Несторовић, Б. (1955), Еволуција београдског стана, Гоgишњак Музеја їраgа Беоїраgа II (Београд): 247-270.

Никић, Љ. (1957), Архитекта Константин Јовановић, ГГБ IV (Београд): 345-360.

Polak, N. (1983), Oblikovanje arhitektonikom, Arhitektura 184-185, ur. Hržić, M. (Zagreb): 32-41.

Premerl, T. (1983), Svaka je arhitektura interpolacija: o interpolacijama zagrebačke međuratne arhitekture, Arhitektura 184-185, ur. Hržić, M. (Zagreb): 70-75.

Ротер-Благојевић, М. (2006), Сйамбена архииеккйура Беоіраgа у XIX и йочейком XX века, Београд: Архитектонски факултет : Орион арт.

Filipović, N. (1983), Interpolacija: sa ili bez propozicija?, Arhitektura 184-185, ur. Hržić, M., (Zagreb): 42-45.

Шћекић, М. (1988), Архииекейа Консиианииин Јовановић, Београд: Музеј града Београда. 


\section{Summary: DUŠICA NIKOLIĆ}

\section{ARCHITECTURAL INTERPOLATIONS IN BELGRADE BY KONSTANTIN JOVANOVIĆ}

The interpolation process is as old as architecture itself, undregoing increasingly significant changes on a daily basis. On the one hand, we experience the raising trend of technical advancements and standards as to the utilization of space, requiring progressive changes; on the other, the movement is developed to protect spatial values that has been based on studying the same. The perspective of interpolation process focuses on the capacity of a society to support this balance. This primarily refers to the development of culture and awareness of those who participate in shaping the environment. If we were to ignore individuality and creativity of architects, we would make new architecture in an old ambient impossible to develop. It should therefore be remembered that the high-quality new architecture in the existing and valued historic environments is in itself the best form of interpolation.

The buildings by this arcitect were constructed with concern for both the visual and aesthetic quality, and their purpose. His buildings in Belgrade have the precision and clarity of performance and architectural consistency with surrounding structures. They cannot be seen merely as functional assemblies, but also as remarkable works of art. This is the result of his versatile personality, talent, great persistence and certainly of the influence of Professor Semper under which Jovanović formed himself as an architect. All this was perfectly implemented in his works, encouraging the spread of European influences in Belgrade, which grew quickly into a metropolis. His works often attracted the attention of fellow architects from Vienna; the building of the National Bank, along with the Cathedral Church, the Metropolitanate Building, and the Residence of Princess Ljubica, was commonly listed among the buildings to see in Belgrade.

The significance of Jovanović's interpolations is reflected in the architectural expression and alignment with social demands. He designed the public buildings to convey the image of power and political progress of a state, while giving the less prominent, residential buildings a more moderate character, but still consistently implementing all the elements of classical renaissance in architecture, which would place him among the most renowned Academician architects. His interpolations are also a good example of moderate and rational contribution to the urban fabric, without exaggerations or pretentiousness. At the time of their creation, they constituted the important part of the city and shaped its urban distinctiveness. Even today, his buildings are recognized as being of exceptional cultural value and significance that any country could be proud of. Jovanović paid particular attention to the ambient in which he was to introduce his work; his buildings are therefore not gaudy but rather meticulously thought out to fit the surrounding space and yet to leave a sufficient impression. His distinctive expression evidenced his skill devoid of any intricacy. His contribution to academic architecture in Serbia ranks him among the most prominent architects this country has ever had, as he possessed the talents of designer, writer, architectural historian, applied artist, and painter.

\section{Illustrations}

Fig. 1 First floor plan, 1922 (National Bank Building, Institute for the Protection of Cultural Monuments, Belgrade 2012)

Fig. 2 National Bank, facade (www.mindono.com)

Fig. 3 National Bank, interior (Politika online, archives)

Fig. 4 Nikola Spasić's Endowment Building (the photograph obtained from http://spomenicikulture.mi.sanu.ac.rs/spomenik.php?id=712)

Fig. 5 Endowment of Nikola Spasić - ground plan (Bogdan Nestorović, Evolucija beogradskog stana, Godišnjak Muzeja grada Beograda II/1955)

Fig. 6 House of Dragomir Radulović, the corner of Vuka Karadžića and Delijska Streets (Photograph: Dušica Nikolić)
Fig. 7 House of Kosta Milenković - ground floor and first floor plan (Bogdan Nestorović, Evolucija beogradskog stana, Godišnjak Muzeja grada Beograda II/1955)

Fig. 8 House of Kosta Milenković (Photograph: Dušica Nikolić)

Fig. 9 House of Jovan Panđela (www.novosti.rs)

Fig. 10 House of Dimitrije Živadinović (Photograph: Dušica Nikolić)

Fig. 11 House of Marko Stojanović (Photograph: Dušica Nikolić) 